\title{
Depositional systems and stratigraphic review proposal of the Rio Preto Fold Belt, northwestern Bahia/southern Piauí
}

\author{
Fabrício de Andrade Caxito*, Alexandre Uhlein, Júlio Carlos Destro Sanglard, Tatiana \\ Gonçalves Dias, Mônica de Cássia Oliveira Mendes
}

\begin{abstract}
The Rio Preto Fold Belt borders the northwestern São Francisco Craton margin, in northwestern Bahia state. The precursor basin to the fold belt is represented by the km-thick Canabravinha Formation, composed of lithic quartzite, phyllite, sandy-pelitic metarhythmite, metadiamictite, and locally metamarl. Its deposition occurred on a submarine slope-apron dominated by gravitational flows like mud flows and turbidity currents in an east-west trending asymmetric rift or hemi-graben, bounded by a faulted border on the south and a possible flexural border towards the north. The sediment supply came mostly downslope from the São Francisco Craton to the south. In the northern portion of the fold belt, the Formosa Formation probably represents part of the Paleoproterozoic basement, composed of garnetmica schist, quartzite, iron-manganese metachert, greenschist, and locally orto-amphibolite intercalations. The Formosa Formation was probably deposited in an arc-related basin $1.9 \mathrm{Ga}$ ago. A stratigraphic review proposal is based on two points: 1) Removal of the Canabravinha Formation from the base of the Bambuí Group and its positioning as a chronostratigraphic equivalent to the diamictite-bearing units on the other fold belts that surround the São Francisco Craton; 2) Replacement of the term Rio Preto Group for the term Formosa Formation, once that its rocks can't be individualized into formations. The pre-orogenic sedimentation on the Rio Preto Fold Belt occurred between 850 and $600 \mathrm{Ma}$ ago. During the Brasiliano Orogeny $(600-540 \mathrm{Ma})$, the sedimentary basin was metamorphosed at the greenschist facies and inverted, assuming a kilometric doubly-vergent fan structure.
\end{abstract}

Keywords: Rio Preto Fold Belt; São Francisco Craton; Brasiliano Orogeny.

Resumo Sistemas deposicionais e proposta de revisão estratigráfica da Faixa Rio Preto, Noroeste da Bahia/Sul do Piauí. A Faixa Rio Preto bordeja a margem noroeste do Cráton do São Francisco, no noroeste do estado da Bahia. A bacia precursora da faixa dobrada é representada pela Formação Canabravinha, de espessura quilométrica, composta por quartzito lítico, filito, metaritmito areno-pelítico, metadiamictito, e, localmente, metamarga. Sua deposição ocorreu em um ambiente de talude submarino dominado por fluxos gravitacionais tais como fluxos de lama e correntes de turbidez, em um rift ou hemi-graben assimétrico de direção leste-oeste, com uma borda falhada a sul e uma possível borda flexural a norte. $\mathrm{O}$ aporte sedimentar foi predominantemente talude abaixo, do Cráton do São Francisco a sul, para norte. Na porção norte da faixa dobrada, a Formação Formosa provavelmente representa parte do embasamento Paleoproterozoico, composta por granada-mica xisto, quartzito, metachert ferro-manganesífero, xisto verde, e localmente, intercalações de orto-anfibolito. A Formação Formosa foi provavelmente depositada em uma bacia relacionada a arco magmático 1,9 Ga atrás. Uma proposta de revisão estratigráfica é baseada em dois pontos: 1) Retirada da Formação Canabravinha da base do Grupo Bambuí e seu posicionamento como um equivalente cronoestratigráfico das formações portadoras de diamictitos das outras faixas dobradas que circundam o Cráton do São Francisco; 2) Substituição do termo Grupo Rio Preto pelo termo Formação Formosa, uma vez que suas rochas não podem ser individualizadas em formações. A sedimentação pré-orogênica na Faixa Rio Preto ocorreu entre 850 e 600 Ma atrás. Durante a Orogênese Brasiliana (600 - $540 \mathrm{Ma})$, a bacia sedimentar foi metamorfisada na fácies xisto-verde e invertida, assumindo uma estruturação quilométrica em leque assimétrico de dupla vergência.

Palavras-chave: Faixa Rio Preto; Cráton do São Francisco; Orogênese Brasiliana.

\section{INTRODUCTION The São Francisco Craton} (Fig. 1) (Almeida 1977, Alkmim 2004) represents a continental fragment involved in the amalgamation of the Western Gondwana paleocontinent during the so-called Brasiliano Orogenic cycle, at the end of the Proterozoic and at the beginning of the Paleozoic (Almeida 1967, 1977, Trompette 1994). During the Neoproterozoic Era, expressive glaciogenic sedimentation developed in the region, being represented by the Jequitaí Formation, in Minas Gerais, and by the Bebedouro Formation, in Bahia. At the same time, in the craton borders, rift basins that evolved into passive margins were developing, with important gravitational sedimentation (debris flow deposits and turbidity currents) and some glacial contribution (Uhlein et al. 2004). These sequences were inverted

Departamento de Geologia, Instituto de Geociências, Universidade Federal de Minas Gerais - UFMG, Belo Horizonte (MG), Brasil. E-mail: boni@ufmg.br, uhlein@dedalus.lcc.ufmg.br, jcsanglard@ymail.com, tatiana.dias@gmail.com,monimendesgeo@yahoo.com.br *Corresponding author 
and metamorphosed during the Brasiliano Orogenic cycle $(\sim 630-570 \mathrm{Ma})$ and have been preserved in the belts surrounding the craton (Fig. 1). Therefore, the fold belts represent the inversion of sedimentary basins adjacent to the craton, a region that has been relatively spared of deformation and metamorphism.

The Rio Preto fold belt (Figs. 1 and 2) is the least studied region in the context of the São Francisco Craton and its marginal fold belts. The objective of this paper is to describe the geology of this area with emphasis on the sedimentary evolution of the precursor basin to the fold belt, besides presenting a proposal of a stratigraphic review based on the Brazilian standards of stratigraphic nomenclature (Código Brasileiro e Guia de Nomenclatura Estratigráfica; Petri et al. 1986). The Rio Preto fold belt is located at the northwest of the state of Bahia, bordering the state of Piauí, where the main urban center is the city of Barreiras (Fig. 1), about $150 \mathrm{~km}$ to the south of Formosa do Rio Preto, on the central portion of the belt.

PREVIOUS STUDIES Compared to other fold belts surrounding the São Francisco Craton,

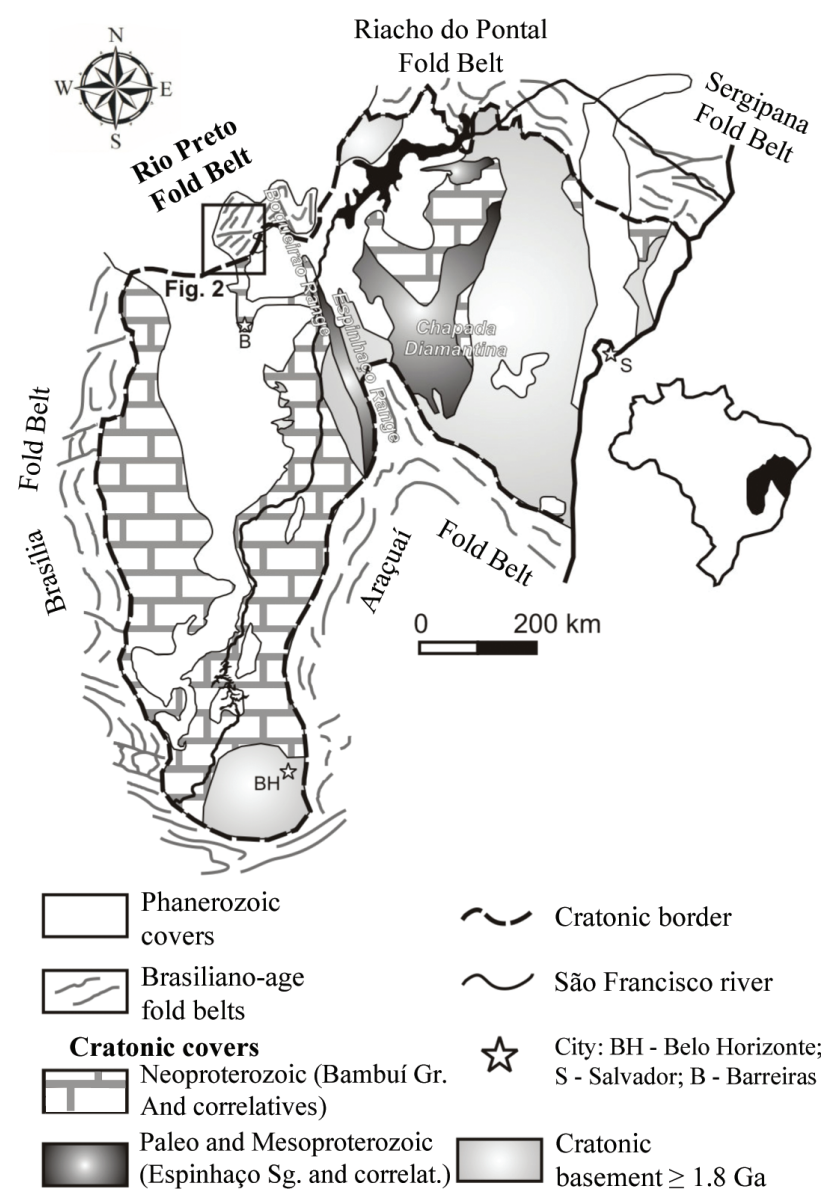

Figure 1 - São Francisco Craton and surrounding belts. Adapted from Alkmim (2004). few studies have addressed the geology of the region. In the 1970's, with the mapping resulting from LETOS Project (Moutinho da Costa et al. 1971) and the study from Santos, Meneses \& Santos (1977), the metasedimentary rocks of Preto river valley were grouped in the Rio Preto Group and stratigraphically placed above the Chapada Diamantina Group, of the mesoproterozoic, and below the Bambuí Group, a neoproterozoic cratonic cover of the São Francisco Craton (Fig. 1). After the disclosure of the geological map to the millionth of the State of Bahia (Inda \& Barbosa 1978), the main geological and tectonic environments of northwestern Bahia were defined, in a geosynclinal context.

Jardim de Sá \& Hackspacher (1980) made a structural pattern recognition on the northwestern margin of the craton, identifying four phases of deformation. These authors placed the Rio Preto Group in the Early Proterozoic because of their correlation with the supracrustal rocks of the Riacho do Pontal fold belt (Fig. 1) that, back then, were considered to be older than those from the Chapada Diamantina Group.

Barbosa (1982) analyzed manganese deposits in the west of Bahia and proposed a Neoproterozoic age for the Rio Preto Group, with almost contemporary deposition with the Bambuí Group. The project RADAMBRASIL also adopts this interpretation (Montes, Monteiro \& Silva 1986).

Egydio-Silva (1987) carried out an important study in the region of Rio Preto Fold Belt and the adjacent cover of the craton, identifying the main lithostratigraphic, structural and tectonic aspects of northwestern Bahia. This author reallocated a major portion of the Rio Preto Group to the base of the Bambuí Group (Canabravinha Formation), thus considering the rest of the group to be correlated to the Chapada Diamantina Group, of Mesoproterozoic age. This interpretation was further adopted by the CPRM - Geological Service of Brazil —, during its basic geological mapping program (Andrade Filho, Neves \& Guimarães 1994, Arcanjo \& Braz Filho 1999).

\section{STRATIGRAPHIC REVIEW PROPOSAL}

The stratigraphic aspects of the Rio Preto fold belt presented in this paper (Fig. 3) are the results from stratigraphic, sedimentological and lithochemical studies, besides being supported by geochronological and isotopic data gathered in the past few years (Uhlein et al. 2008, Sanglard et al. 2008, Gonçalves Dias \& Mendes 2008, Caxito 2010, Caxito et al. 


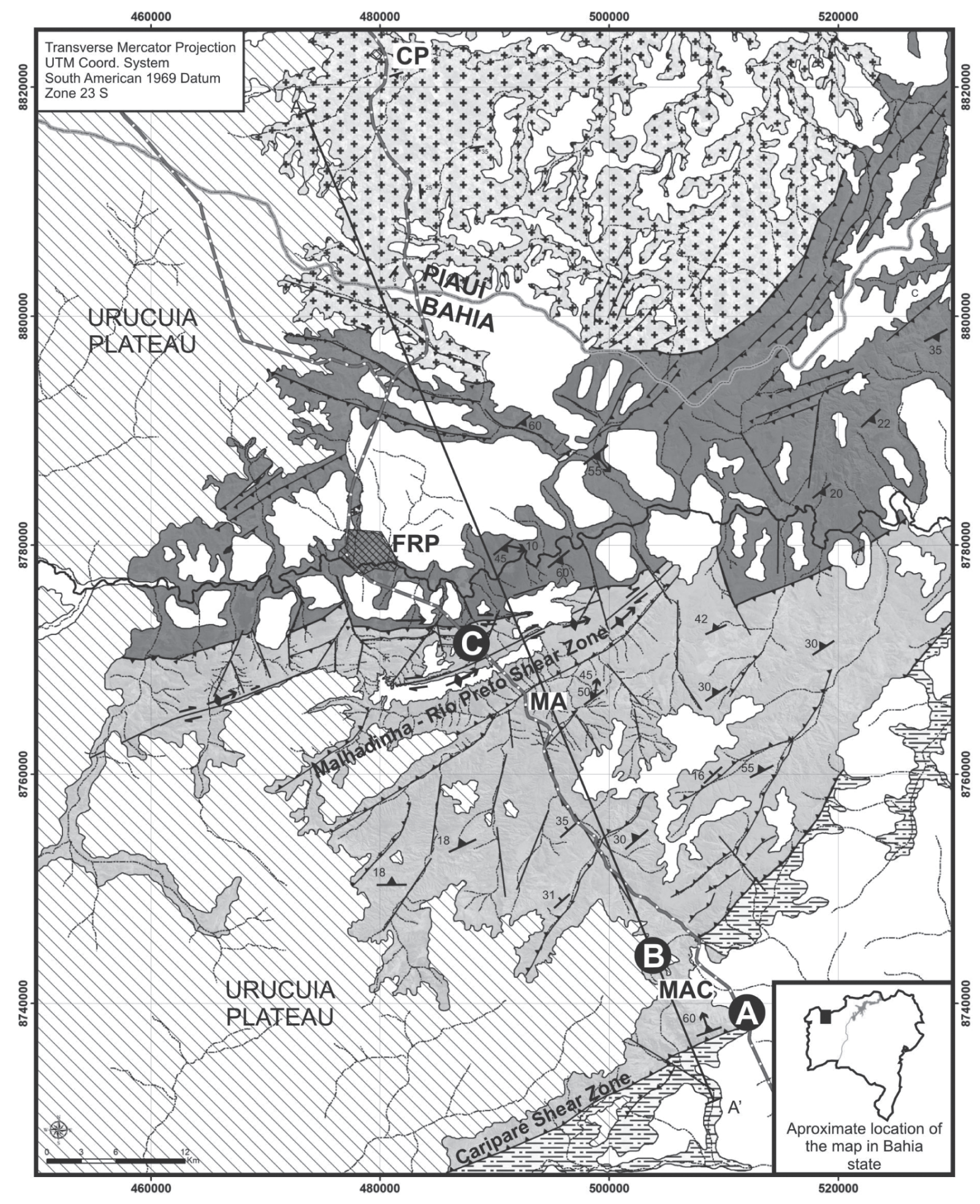

\begin{tabular}{|c|c|c|}
\hline $\begin{array}{l}2 \text { Preto river } \text { BR-135 road } \\
\text { Interstate border } \\
\text { MAC - Creek } \\
\text { Cenozoic covers } \\
\text { MAC - Monte Alegre } \\
\text { Cretaceous } \\
\text { Urucuia Group } \\
\text { Sandstone, conglomerate }\end{array}$ & 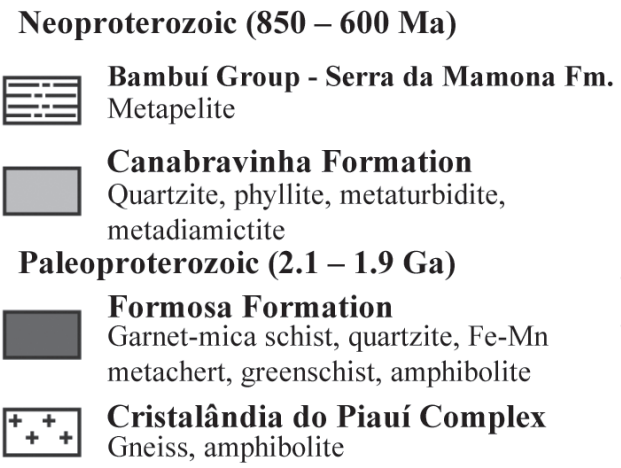 & $\begin{array}{l}\mathrm{S}_{1} / / \mathrm{S}_{0} \text { - bedding } \\
\mathrm{S}_{2} \text { - crenulation foliation } \\
\mathrm{S}_{2} \text { - sub-vertical } \\
\mathrm{L}_{2} \text { - mineral lineation } \\
\text { Frontal thrust shear zone } \\
\text { Transcurrent shear zone } \\
\text { Photo-interpreted lineament } \\
\text { Location of stratigraphic } \\
\text { columns of Fig. } 3\end{array}$ \\
\hline
\end{tabular}

Figure 2 - Geological map of the Rio Preto belt, northwestern Bahia and southern Piaui. See Fig. 1 for location. 
2011a, b). The stratigraphy herein proposed differs from that proposed by Egydio-Silva, Karmann \& Trompette (1989), suggesting the removal of the Canabravinha Formation from the Bambuí Group, and the change of denomination of the Rio Preto Group into Formosa Formation, of Paleoproterozoic instead of Mesoproterozoic age, as previously suggested (Tab. 1). Next, we will present the main lines of reasoning and argumentation in which this proposal of stratigraphic review is based on.

\section{Cristalândia do Piauí Complex}

The tecton-

ic-stratigraphic basement of the Rio Preto fold belt is represented by the Cristalândia do Piauí Complex, in the northern part of the fold belt (Fig. 2) (Arcanjo \& Braz Filho 1994), which comprises intercalations of biotite gneiss and amphibolite. These rocks are aged 2.1 Ga ( $\mathrm{Rb}-\mathrm{Sr}$ whole rock isochron), with biotites dating around $540 \mathrm{Ma}$ (K-Ar) (Egydio-Silva 1987). Sm-Nd model ages (Tdm) in between 2.8 and $2.6 \mathrm{Ga}$ suggest that Archean crust is the main component of this segment (Caxito 2010 and new data), with the impression of a paleoproterozoic cycle and rework during the Brasiliano cycle. The geology of this complex is relatively unknown and requires further studies, especially regarding petrography and lithochemistry.

\section{Formosa Formation The Formosa Formation} corresponds to the Rio Preto Group according to Egydio-Silva, Karmann \& Trompette (1989). The name Rio Preto Group was informally proposed by Santos, Meneses \& Santos (1977) to denominate the metasedimentary rocks of the Preto river valley. However, as Fuck et al. (1993) states, the Rio Preto unity should not be considered as a group, for its rocks are not naturally subdivided in formations. According to the Brazilian Code of Stratigraphic Nomenclature, "the formations are fundamental units in the description and interpretation of a region's geology, especially regarding the spatial distribution of successions and deposition in areas that are proximal and distal within the basin." (Petri et al. 1986, p. 377, § 1). Thus, Uhlein et al. (2008) and Caxito (2010) suggest a redefinition of this group based on genetic criteria and according to the limitations of stratigraphic studies on Precambrian regions, comprising the Canabravinha and Formosa Formations. However, recent geochronological and isotopic data suggest that the two formations developed in different contexts and ages, so they should not be included in the same group (Caxito et al. 2011a, b). Hence, the term "Rio Preto Group" is no longer used.

The Formosa Formation (named after the city of Formosa do Rio Preto) originates in the setentrional portion of the Rio Preto fold belt, alongside Preto river, and extends $20 \mathrm{~km}$ to the north, towards the Bahia and Piauí boundary (Fig. 2). It is composed of muscovite schist, often with abundant garnet, with intercalations of micaceous quartzite, sandy metarhythmite, iron-maganese metachert, chlorite-actinolite-epidote schist (greenschist), and, locally, orthoamphibolite (Figs. 3 and 4). The stratotype can be observed on BR-135 road, between Formosa do Rio Preto and the borderline of Bahia and Piauí (Figs. 2 and 4B). Subsidiary reference sections in which the intercalations of metachert and greenschist may be easily observed are indicated at Vereda Jatobá and in the region of Arroz Village, to the east and northwest of Formosa do Rio Preto, respectively. Metric intercalations of micaceous quartzite are seen in the road to Coaceral (Portal do Jalapão) near the limits of Bahia-Piauí (Fig. 4A). The lithotypes in Formosa Formation present a metamorphism of greenschist to epidote-amphibolite facies $\left(\sim 500^{\circ} \mathrm{C}, 2-5 \mathrm{Kbar}\right.$, $10-20 \mathrm{~km}$ depth; Caxito, 2010). Due to the tectonism of the Formosa Formation, with frontal and lateral low-angle thrusts (Fig. 4B), it is virtually impossible to estimate its thickness; however, constant intercalations of gneiss slivers from the basement suggest preserved low thickness.

Table 1 - Proposal of stratigraphic review of the Rio Preto fold belt

\begin{tabular}{|c|c|c|c|c|}
\hline \multicolumn{3}{|c|}{ Egydio-Silva et al. (1989) } & \multicolumn{2}{|r|}{ This study } \\
\hline Neoproterozoic & $\begin{array}{l}\text { Bambui } \\
\text { Group }\end{array}$ & $\begin{array}{l}\text { Riachão das Neves Fm. } \\
\text { Serra da Mamona Fm. } \\
\text { São Desidério Fm. } \\
\text { Canabravinha Fm. }\end{array}$ & $\begin{array}{l}\text { Neoproterozoic } \\
\text { Cryogenian/Ediacaran } \\
(850-600 \mathrm{Ma})\end{array}$ & $\begin{array}{ll}\begin{array}{l}\text { Bambui Group } \\
\text { (craton) }\end{array} & \text { Serrachão das Neves Fm. } \\
& \text { São Desidério Fm. } . \\
\text { Canabravinha Fm. } \\
\text { (fold belt) }\end{array}$ \\
\hline Mesoproterozoic & Rio Pret & Group & $\begin{array}{l}\text { Paleoproterozoic } \\
\text { Orosirian }(\sim 1.9 \mathrm{Ga})\end{array}$ & Formosa Fm. \\
\hline Archean/Paleoproterozoic & Cristalầ & dia do Piauí Complex & Archean/Paleoproterozoic & Cristalândia do Piaui Complex \\
\hline
\end{tabular}


Good occurrences of iron-manganese metachert can be found in the Jataí region, $20 \mathrm{~km}$ to the east of Formosa do Rio Preto (Figs. 4C and D), on the road to Santa Rita de Cássia, and in the Lagoa Farm, on the old BR-135 road, which is accessed through the wooden bridge crossing Preto river in Formosa do Rio Preto, towards the southeast. This rock constitutes a guide-layer for the Formosa Formation that has been previously described as itabirite (Egydio-Silva 1987, Andrade Filho, Neves \& Guimarães 1994). Recently, Gonçalves Dias \& Mendes (2008) and Mendes et al. (2008) carried out petrographic and litochemical studies, aided by scanning electron and optical microscopy (Fig. 4D), indicating its classification as metachert,

SSE

NNW

\section{Canabravinha Formation}

$850-600 \mathrm{Ma}$

\section{Column C}

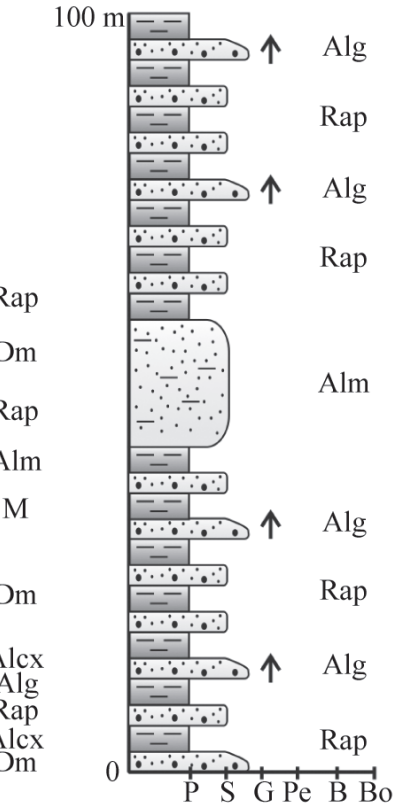

Erosive Unconformity
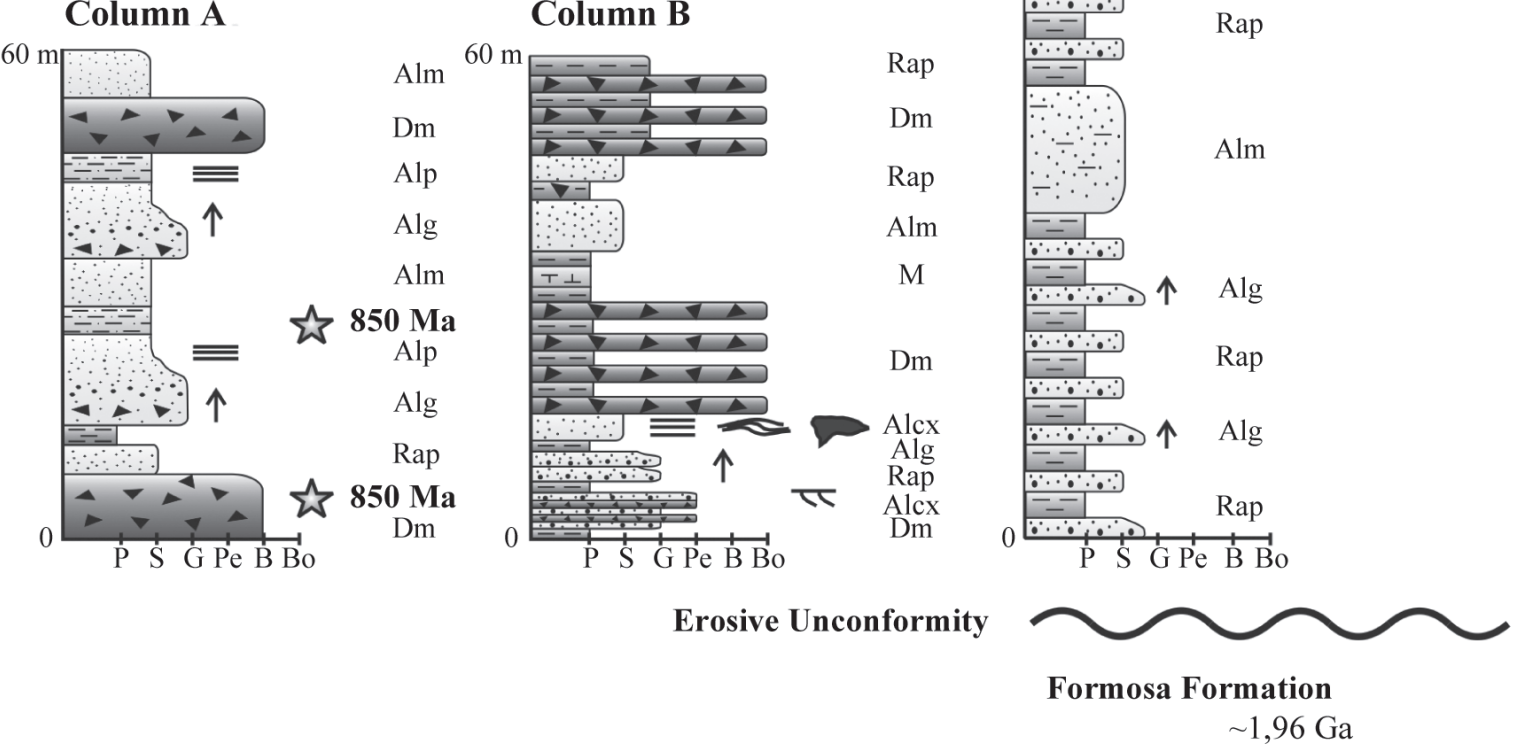

Alm 60
Dm
Alp
Alg
Alm
850 Ma
Alp
Alg
Rap
$\mathbf{8 5 0 ~ M a ~}$
Dm

Column B

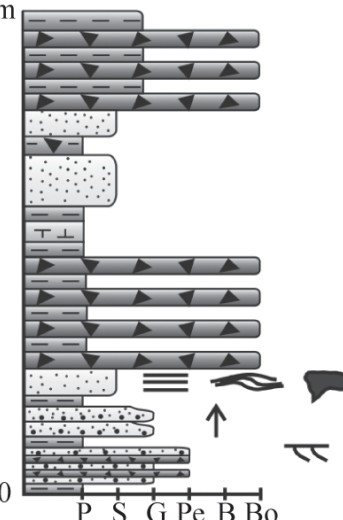

Iron-rich schist

Garnet-mica schist

Carbonaceous phyllite/schist

Sandy-pelitic metarhythmite Dm Facies code on Table 2

Micaceous quartzite

Lithic quartzite / graywacke $\uparrow$ Graded bedding

(coarse to fine)

Sandy metabreccia

$\equiv$ Plane-parallel stratification

Metadiamictite

Tा Cross bedding

Metamarl

Fe-Mn Metachert

Greenschist

Ortho-amphibolite

Gneiss

$\approx$ Climbing ripple

P Phyllite clasts

w

$\mathrm{U}-\mathrm{Pb}$ zircon age /

Youngest detrital zircon population age

$\mathrm{P}$ - pelite, $\mathrm{S}$ - sand, G - granule,

Pe - pebble, B - block, Bo - boulder

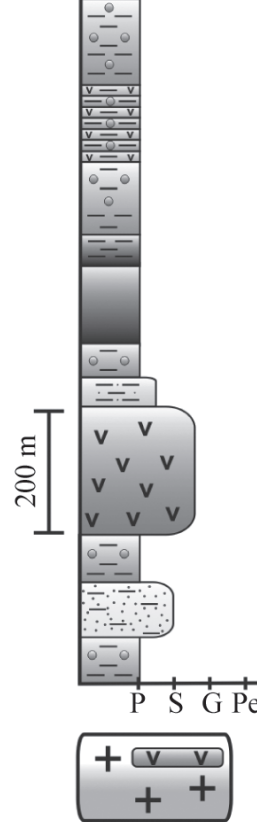

$2.1 \mathrm{Ga}$

茮 $1.961 \pm 11 \mathrm{Ma}$

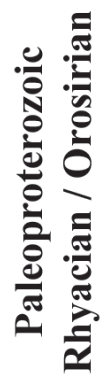

解 $1.9 \mathrm{Ga}$

ndia do

Piauí Complex

$\geq 1.9 \mathrm{Ga}$

Figure 3 - Stratigraphic relations in the Rio Preto fold belt according to the proposal of our study. Note the change in scale between the columns of Canabravinha and Formosa formations. 
with $\mathrm{SiO}_{2}$ between 90.49 and $99 \%$, Mn between 0.04 and $3.54 \%$, and Fe between 0.4 and $2.4 \%$.

Metric to decimetric intercalations of greenschist with nematoblastic texture are common in the Formosa Formation. These are mainly composed of chlorite, actinolite, epidote and plagioclase strongly oriented in the main foliation. The most important accessory mineral is titanite. Tectonic intercalations of gneiss slivers of the Cristalândia do Piauí Complex are also found in the Formosa Formation, especially in Arroz Village and near the BR-135, to the north of Formosa do Rio Preto.

In the Angico Farm, to the west of Formosa do Rio Preto, a 200 meters thick epidote-amphibolite layer intercalates between garnet-mica schist and sandy metarhythmite of the Formosa Formation. These rocks have long been considered as essential for the understanding of the geodynamic evolution in Rio Preto belt (EgydioSilva 1987, Fuck et al. 1993, Uhlein et al. 2008). The amphibolites present lithochemistry of tholeiitic basalts, with flat chondrite-normalized rare earth elements (REE) patterns and slight enrichment of light REE compared to heavy $\operatorname{REE}\left(\mathrm{La}_{\mathrm{N}} / \mathrm{Yb}_{\mathrm{N}}: 1.35-2.97 ; \mathrm{Eu} / \mathrm{Eu}^{*}: 0.94-1.14\right)$, negative $\mathrm{Nb}$ and positive $\mathrm{Sr}$ anomalies, and high LIL/HFS ratio (Caxito 2010, Caxito et al. 2011b). In most tectonic discrimination diagrams, the samples plot within island-arc tholeiites, back-arc basalt or Mid Ocean Ridge Basalt (MORB) fields. U-Pb analyses of magmatic zircons (Th/U: $0.11-1.56)$ yield a homogeneous population aging 1,961 $\pm 11 \mathrm{Ma}$, with $\varepsilon \mathrm{Nd}_{(1.96)}$ ranging from slightly negative to positive $(-0.3$ to +1.0$)$. Thus, these rocks probably represent oceanic crust remnants, derived from a mantle wedge above a subduction zone that may be related to a paleoproterozoic volcanic arc (Caxito 2010, Caxito et al. 2011b).

Studies of detrital zircon and Nd isotopes suggests a relative simple sedimentary provenance for the Formosa Formation, with a bimodal distribution of detrital zircon U-Pb ages in between $1.9-2.2$ and $2.5-$ $2.6 \mathrm{Ga}$, and $\mathrm{T}_{\mathrm{DM}}$ model ages between 1.9 and $2.6 \mathrm{Ga}$ (Caxito 2010, Caxito et al. 2011a). These data seem to indicate the Cristalândia do Piauí Complex as the main source of the Formosa Formation. The absence of meso - to neoproterozoic zircons and the intercalation of paleoproterozoic mafic rocks suggest that at least part of the Formosa Formation was formed in
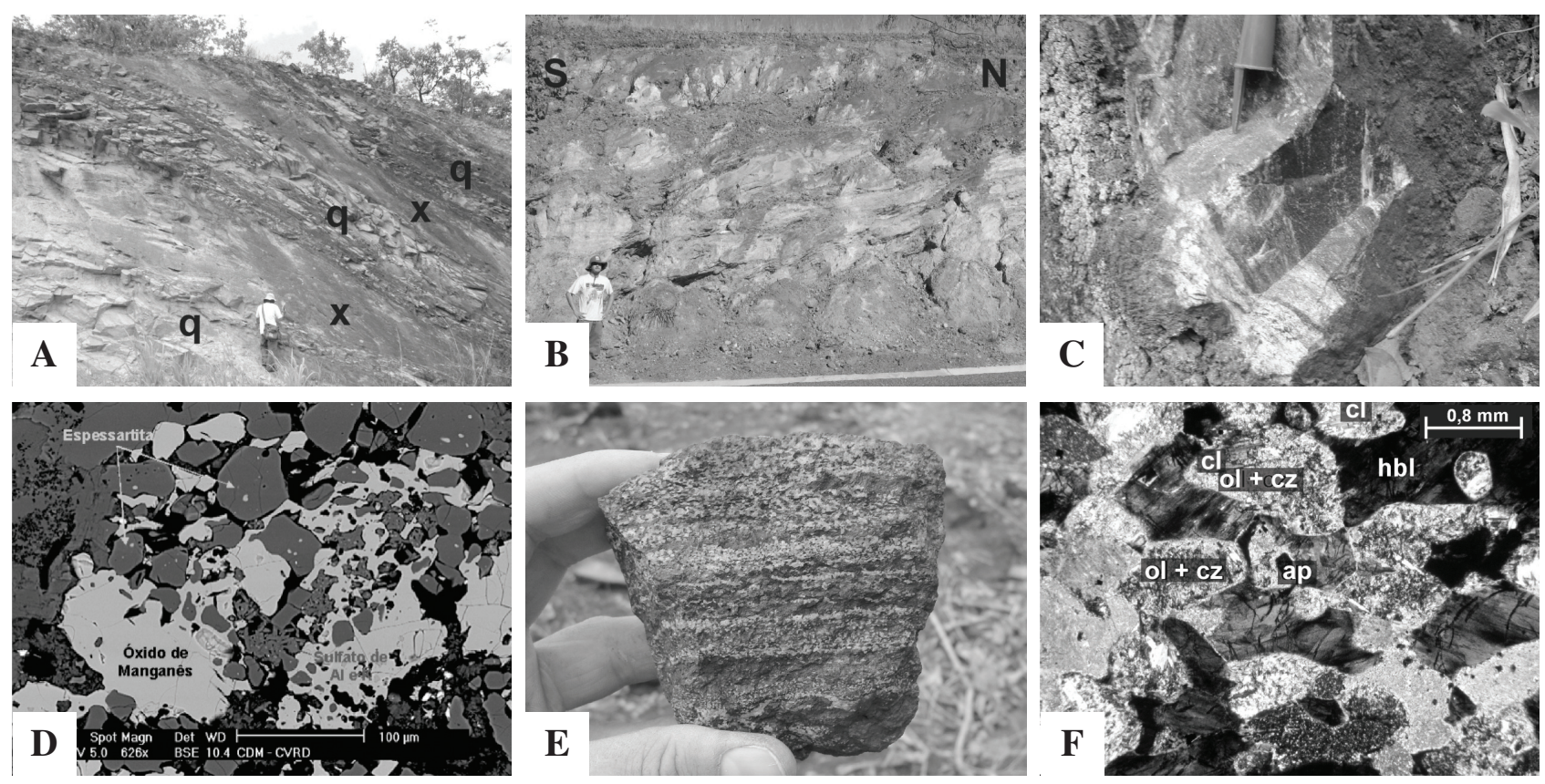

hbl: hornblende; ol: oligoclase; cz: clinozoisite; cl: chlorite; ap: apatite.

Figure 4-Lithotypes of Formosa formation. (A) Intercalations of garnet-mica schist $(x)$ and micaceous quartzite (q), road to Coaceral (Portal do Jalapão); (B)Mica schist in the BR-135 road, north of Formosa do Rio Preto, with deformation characterized by low angle thrusts; (C) Iron-manganese Metachert, Primavera farm, east of Formosa do Rio Preto; dark iron and manganese oxide rich layers alternate with quartz-rich layers; (D) aspect of dark metachert layer at the scanning electron microscope, formed mainly by espessartite and manganese oxides. (E) Ortho-amphibolite at Angico farm, west of Formosa do Rio Preto; clear plagioclase-rich layers (albite and oligoclase) alternate with mafic amphibole-rich layers (mainly hornblende); (F) microscopic aspect of ortho-amphibolite from Angico farm. 
the Paleoproterozoic Era, probably in a basin related to a magmatic arc, hence composing the basement to the Rio Preto fold belt alongside the Cristalândia do Piauí Complex. The Formosa Formation contacts the Canabravinha Formation in the south through an oblique reverse dextral shear zone (MalhadinhaRio Preto Shear Zone, Gonçalves Dias \& Mendes 2008, Caxito et al. 2010), and in the north it thrusts in low-angle the gneisses of the Cristalândia do Piauí Complex. To the east, the Formosa formation is thrusted upon the quartzites of the Santo Onofre Group, in Serra do Boqueirão (EgydioSilva 1987). The high degree of transposition of older structures by crenulation cleavage $\left(\mathrm{S}_{2}\right)$ dating from the Brasiliano cycle (600 - $540 \mathrm{Ma}$, K-Ar in muscovite, Egydio-Silva 1987) makes it hard to recognize possible paleoproterozoic-related deformational structures.

\section{Canabravinha Formation The Canabravinha} Formation was defined by Egydio-Silva , Karmann \& Trompette (1989) as the basal unity of the Bambuí Group in the region, being related to the Bebedouro Formation, base of the Una Group, in Bahia. The nomenclature refers to the Canabravinha stream, which runs next to the homonymous farm, in the municipality of Monte Alegre dos Cardosos, where the authors made the schematic section of the formation.

Uhlein et al. (2008) and Caxito (2010) suggest the removal of the Canabravinha Formation from the Bambuí Group, due to its kilometric thickness, greenschist facies metamorphism, and significant deformation, which are characteristics of deposition and structural evolution in the context of a fold belt, in contrast to the Bebedouro Formation, which presents a thickness of hundreds of meters and low to null deformation and metamorphism, which suggest evolution in a cratonic context. Although both unities could present chronostratigraphic correlation, the tectonic and sedimentary contexts are quite different. The Canabravinha Formation thrusts the Bambuí Group in the southern portion of the fold belt (Cariparé shear zone), so the original contact relations between these two units are not recognized. Therefore, it is more coherent that the Canabravinha Formation be correlated to the diamictite-bearing formations from the other Brasiliano fold belts (i.e. basal formations of the Macaúbas Group, in Araçuaí belt, Capitão-Palestina Formation, in the Sergipana belt, and the Ibiá Group, in the Brasília belt).
The Canabravinha Formation occurs in the southern portion of the Rio Preto belt, from north of Cariparé towards north for almost $40 \mathrm{~km}$ (Fig. 2). It is composed of lithic, conglomeratic, feldspathic, carbonatic or micaceous quartzite with graded, plain or cross stratification; metagraywacke, carbonaceous phyllite and mica schist; sandy metarhythmite; metadiamictite, and metamarl (Fig. 5). Millimetric to centimetric euhedral 1imonite is profusely disseminated. Besides the section of Canabravinha stream, in the BR-135 road, between Cariparé and Formosa do Rio Preto, metarythmites are easily seen. The Canabravinha formation presents a lateral and vertical variation with coarse lithofacies to the south, progressively gradating to lithofacies presenting a higher proportion of pelitic material towards the north.

The spectrum of $\mathrm{U}-\mathrm{Pb}$ ages in detrital zircon of the Canabravinha Formation differs from that of the Formosa Formation, varying from 3,000 to $850 \mathrm{Ma}$. The $\mathrm{Nd}$ isotopes also indicate a larger variety of sources, with $\mathrm{T}_{\mathrm{DM}}$ model ages in between 1.5 and $2.7 \mathrm{Ga}$ (Caxito 2010, Caxito et al. 2011a). These data suggest that the Canabravinha and Formosa formations present geological evolution in different contexts, i.e. they are probably not chronologically correlated. So, geochronological data do not support the allocation of both formations in the same group, as previously proposed (Rio Preto Group, Uhlein et al. 2008, Caxito 2010). We assume the hypothesis that the Formosa Formation represents part of the paleoproterozoic basement of the Rio Preto belt, while the Canabravinha Formation represents the neoproterozoic sedimentation in the fold belt precursor basin.

The Canabravinha Formation is characterized by a low to medium-grade metamorphism and complex structural geology related to the Brasiliano Orogeny, as indicated by K-Ar ages in muscovite around 590 Ma, obtained by Egydio-Silva (1987). To the south, it is thrust upon the Serra da Mamona Formation of the Bambuí Group by a frontal reverse shear zone (Cariparé shear zone) (Figs. 2 and 7), and to the north it contacts the Formosa formation through an oblique dextral shear zone (Malhadinha-Rio Preto Shear Zone) (Figs. 2 and 7). Based on gravimetric data, Egydio-Silva (1987) estimates a thickness of almost 7,500 meters for the Canabravinha Formation. However, this data must be carefully interpreted, due to the high ductile deformation of these rocks, presenting isoclinals folds in the central portion of the fold belt (Fig. 2 and 7). 
Bambuí Group The Bambuí Group in the western part of Bahia has been subdivided into three formations by Egydio-Silva, Karmann \& Trompette (1989), including, from the bottom up:

1) São Desidério Formation. Dark gray limestones with intercalations of marls and siltstones, with estimated thickness of 450 meters. The basal contact is not observed; however, if we admit a correlation to the Sete Lagoas Formation, to the south, nearby Correntina, the latter settles by erosive discordance over gneisses of the Archean/Paleoproterozoic basement of the São Francisco Craton. The superior contact is gradational, with progressive increase in the proportion of clastic material in carbonates, grading to the metamarls and carbonaceous slates of the Serra da Mamona Formation.

2) Serra da Mamona Formation. It can be correlated to the Serra da Saudade Formation, and it is marked by the intercalation of metacarbonate and metapelite layers with incipient to low metamorphic grade. Thickness, according to the geological profile, is estimated in 3,000 meters (Egydio-Silva, Karmann \& Trompette 1989), but these authors call the attention to the fact that it is a region of intense tectonic deformation, thus this estimate must be carefully considered.

3) Riachão das Neves Formation. On top of Serra da Mamona Formation, the lithotypes show a
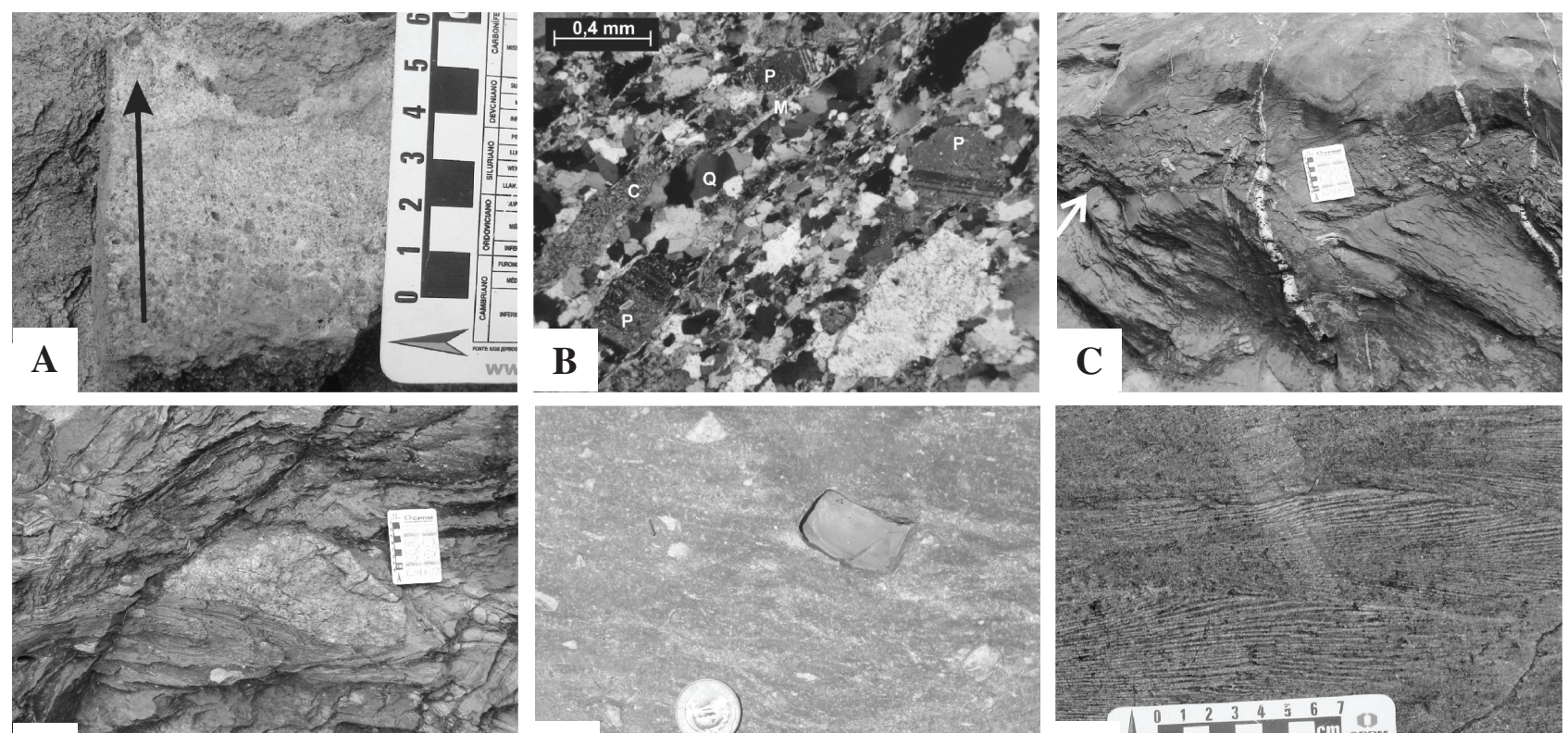

D
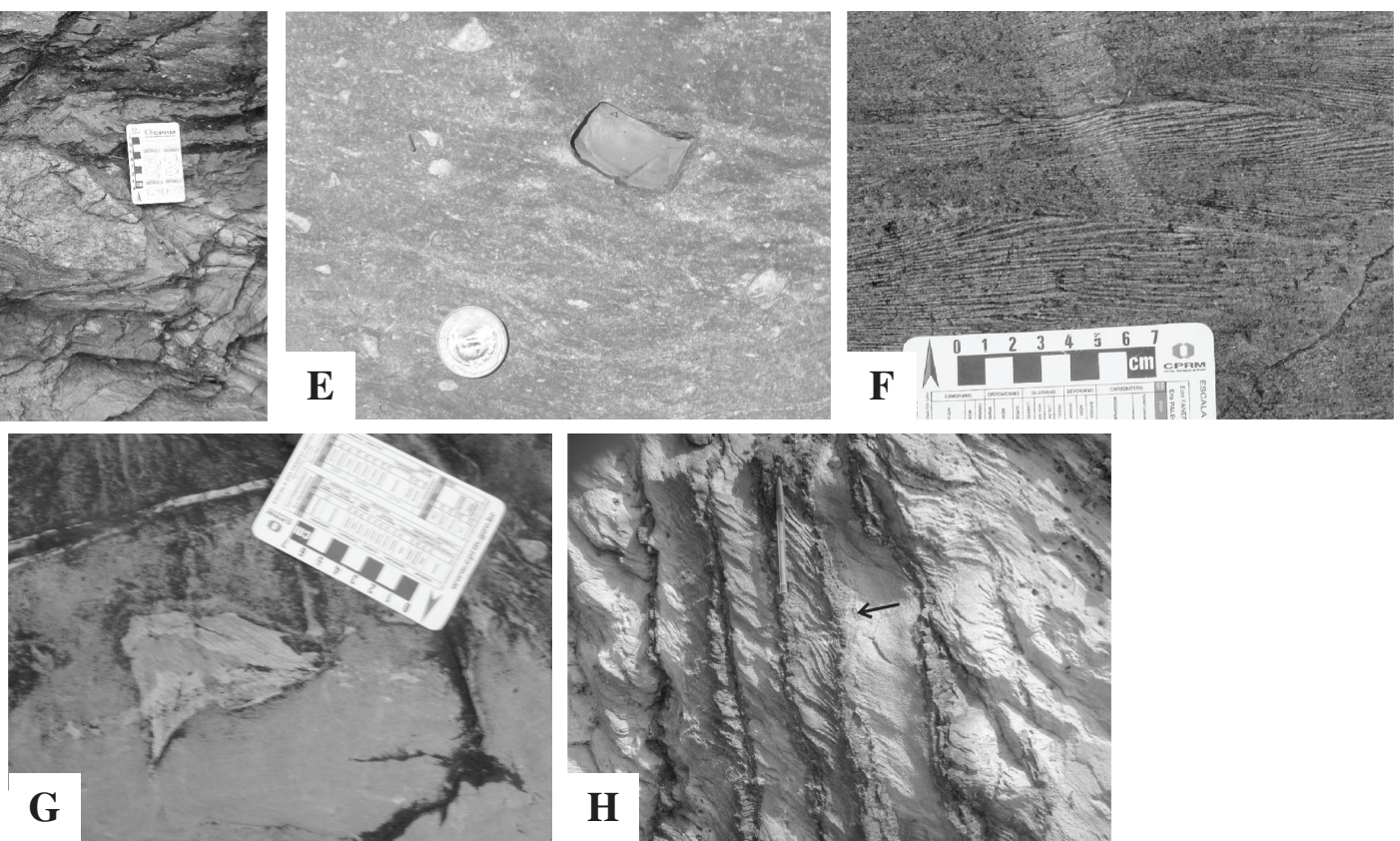

(A, B): Column A, Chapada da Boa Vista; (C-G): Column B, Canabravinha stream; (H): Column C, BR-135 between Malhadinha and Formosa do Rio Preto.

Q: quartz; P: plagioclase; C: carbonate; M: muscovite.

Figure 5 - Lithotypes of Canabravinha formation. (A) Graded stratiphication in lithic quartzite; (B) Photomicrograph under crossed polarizers of lithic quartzite. (C) Decimetric layer of metadiamictite intercalated within carbonatic phyllite. Note the absence of isolated clasts in the phyllite layer; (D) Detail of granite boulder in the metadiamictite layer; (E) carbonate pebble and quartzite clasts in the metadiamictite layer; (F) Climbing laminations in the quartzite layer; $g$ ) phyllite clast in the quartzite layer; $(H)$ low-density metaturbidites. Centimetric sandy layers, in clear grey, intercalated within dark grey pelitic layers. The arrow indicates graded stratiphication in the quartzite layer. 
gradual increase of sedimentary granulometry, presenting a great amount of feldspar and lithic fragments in its composition, thus characterizing meta-arkoses and metagraywackes of the Riachão das Neves formation. This formation can be correlated to the Três Marias Formation, with estimated thickness of 4,000 meters.

Phanerozoic covers Above the Precambrian units of the region, lies the Urucuia Group upon an erosive and angular discordance, which is constituted by fluvial/aeolian sandstones and conglomerates of the Cretaceous period. All of the units are covered by unconsolidated sedimentary deposits from the Cenozoic Era, mostly sand and clay, often lateritized.

\section{DESCRIPTION OF STRATIGRAPHIC}

COLUMNS Aiming at a stratigraphic and sedimentological study of the Rio Preto belt, three schematic columns were raised at the Canabravinha Formation, looking to recognize the main lithofacies and depositional systems in key-areas of the region (Figs. 2 and 3). It is worth emphasizing the schematic character of such columns, inherent to studies of this type in fold belts. The column correlation method was chosen due to the visual practicality of stratigraphic and sedimentological relations in time and space.

Column A (Fig. 3) was raised in Chapada Boa Vista, near the tectonic contact with Serra da Mamona Formation (UTM 512249E/8738285N; Datum SAD69 Zone 23S, being the same for all other columns). One can observe a sequence dominated by coarse grained lithofacies, mainly psamopsephitic deposits. The basal metadiamictite in this column is found on road BR-135 and is estimated to be 10-meter thick (Fig. 3). The metadiamictite presents a metapelitic matrix that sustains clasts of granule to block size of orthoquartzite, limonitic micaceous quartzite, carbonates, quartz, gneiss, and granite. The original geometry of the clasts is currently obliterated by their stretching in the $\mathrm{S}_{2}$ foliation, due to the proximity to the Caripare shear zone, the limitation between the craton and the fold belt (Egydio-Silva 1987) (Fig. 2).

In the intermediate portion of Column A, granodecrescent sequences of granule to pebble sandy metabreccia, lithic quartzite with coarse to fine graded stratification, and sandy-pelitic metarhytmite with plain-parallel stratification are found (Fig. 5A). The quartzite is usually poorly selected and presents low textural and mineralogical maturity, thus angular to sub-angular grains predominating (Fig. 5A). Microscopic analyses (Fig. 5B) showed quartzite is composed of quartz, muscovite, carbonate, plagioclase, gneiss, feldspar, granite, limonite and opaques, so it can be classified as coarse lithic to conglomeratic or carbonatic quartzite. On the top of the scarp, metadiamictite with block-sized clasts is found again, which characterizes the cyclicity of the sedimentation processes.

Column B was raised throughout the draining of the Canabravinha stream, near Monte Alegre dos Cardosos (504030E / 8744592N). The sequence is similar to that of Column A, although the metadiamictite layers are less thick and decimetric, and the phyllites and quartzites are more common (Figs. 5C-G). In the metadiamictite layers, clasts of carbonate, gneiss, quartz, quartzite, and granite (sensu lato) are found (Figs. 5D and E). Clasts of metadiamictite within the metadiamictite layers are rare. Clasts of granite, gneiss and quartzite present granulometry of granule to boulder, while the carbonate clasts occurre mostly on granule to pebble granulometry. The original geometry of these clasts remains well preserved, without a dominant pattern, commonly varying from sub-angular to sub-rounded types (Figs. 5C-E); however, rounded and angular clasts, presenting low sphericity, are also common. The matrix is mainly formed by carbonates and oriented phyllosilicates (white mica), and stretched quartz according to the main foliation $\left(\mathrm{S}_{2}\right)$. Metadiamictite layers intercalate with phyllite and quartzite layers, which do not present isolated clasts (Fig. 5C). The proportion of carbonate is sometimes very expressive, constituting layers of metamarl.

In the quartzite layers, centimetric climbing laminations are found (Fig. 5F), as well as phyllite clasts (Fig. 5G) with irregular geometry, highly angulated, chaotically disseminating within the quartzite.

Column $\mathrm{C}$ was raised on BR-135 road, between Malhadinha and Formosa do Rio Preto (488396E/8771374N). In this region, we observe a predominance of metarhythmites formed by centimetric to decimetric intercalations between metagraywackes with graded coarse-fine stratification and phyllites/schists (Fig. 5H), mostly carbonaceous and manganesiferous, with local layers of quartzite. It is interesting to note the rhythmic occurrence of manganese low-thickness crusts intercalated within the lithotypes, parallel to the bedding plane (Fig. $5 \mathrm{H}$ ). 
FACIES, SEDIMENTARY ENVIRONMENTS AND DEPOSITIONAL SYSTEMS OF THE CANABRAVINHA FORMATION Fig. 3 presents a correlation of the three graphic-sedimentary profiles raised in the study, representing the main lithofacies associations throughout the Canabravinha Formation. Coarse facies (metadiamictites) are prevalent in the south portion, becoming thinner to the north. Tab. 2 shows the main facies, processes and products interpreted on the stratigraphic columns. Based on this data, one can identify the depositional environments and propose a model of evolution for the precursor basin to the fold belt.

The decimetric to metric layers of metadiamictite suggest the periodic action of mud and debris flows that occasionally grades to high-density turbidity currents (granule and pebble metabreccia) (Lowe 1982), and these to low-density currents, with Tabc intervals of Bouma (1962), represented by conglomeratic to coarse lithic quartzite with graded, plane and crossed stratification, according to the velocity of the current flow. The intercalated phyllite layers are the product of decantation of fines in suspension, which is generated after each mudflow. The presence of climbing laminations (Tc) and phyllite clasts within quartzite intercalating with metadiamictite layers also indicate the action of turbidity currents during the sedimentation of such layers. The climbing laminations are formed when tractive sedimentary processes compete with sedimentation by decantation, as in the case of decelerating flows such as turbidity currents; Phyllite clasts are widely disseminated in sand layers of turbidity sequences, being formed mainly by erosive processes of the clayey soil during gravitational flows (Johansonn \& Stow 1995).

In general, the disposition of the facies of metarhythmites in Column $\mathrm{C}$ follows the classic scheme of low-density turbidites, of Bouma (1962).
Metaturbidites are formed by centimetric layers of metagraywacke with coarse-fine graded stratification (Ta), followed by metagraywacke with plane stratification/lamination $(\mathrm{Tb})$, rarely crossed stratification (Tc), followed by phyllite/schist layers (Tde). These are superimposed by another metagraywacke layer followed by another phyllite layer, and so on. Similar outcrops are common on road BR-135, between Malhadinha and Formosa do Rio Preto, which suggest a predominance of diluted turbidity currents in this portion of the precursor basin.

The sedimentary/stratigraphic analysis showed no direct evidence of glacial influence on the sedimentation of the Rio Preto belt. Although diamictites have been recognized for over 50 years as important facies in depositional systems that are not related to glacial sedimentation, the distinction between glacial and non-glacial diamictites is still neglected. Some good reviews on the theme and distinction criteria between glacial and non-glacial diamictites can be found in the works of Schermerhorn (1974), Boulton \& Deynoux (1981), Dreimanis \& Schucluter (1985), Moncrieff (1989), Eyles (1993), Miller (1996) and Uhlein et al. (2004). The intercalation of thin layers (decimeters to meters) of diamictites with sandstones and pelites, deposited in submarine conditions, and the association with turbidites, do not allow defining these rocks as tillites (glacio-terrestrial rock). Glacio-marine sedimentation is not supported either, for in such case one would expect to find isolated clasts in rhythmites and pelites away from the mud flows of Columns A and B, i.e., in Column C. The hypothesis of reworking glacial deposits by gravitational submarine flows cannot be excluded; however, the lack of identification of striated, faceted or pentagonal clasts makes it only conjectural. Nevertheless, times of low sea level stand, such as glacial periods, strongly favor the development of slope-aprons and

Table 2 -Lithofacies identified in the stratigraphic columns of Canabravinha Formation, with the interpretation of the main products and sedimentation processes

\begin{tabular}{|c|c|c|c|}
\hline Facies & Products & Processes & Columns \\
\hline Dm & $\begin{array}{l}\text { Massive diamictite with pelite-carbonatic matrix, containing carbonate, } \\
\text { gneiss, quartzite, quartz and granite clasts. }\end{array}$ & Mud flows & $\mathrm{A}$ and $\mathrm{B}$ \\
\hline $\begin{array}{l}\text { Alm } \\
\text { Alg } \\
\text { Alp } \\
\text { Alcx }\end{array}$ & $\begin{array}{c}\text { Lithic sandstone composed of quartz, carbonate, gneiss, feldspar and } \\
\text { muscovite grains, massive (m), with coarse-fine graded stratification (g), } \\
\text { plane-parallel stratification (p) or crossed stratification (cx), locally with } \\
\text { climbing laminations and shale clasts. }\end{array}$ & $\begin{array}{l}\text { Low to high density turbidity } \\
\text { currents (Tabc) }\end{array}$ & $\mathrm{A}, \mathrm{B}$ and $\mathrm{C}$ \\
\hline M & e & $\begin{array}{l}\text { Reworking of carbonate } \\
\text { debris, precipitation }\end{array}$ & B \\
\hline Rap & $\begin{array}{l}\text { Sandy-pelitic rhythmite, formed by centimetric to decimetric plane-parallel } \\
\text { layers of sandstone and pelite, often carbonaceous and/or manganesiferous. }\end{array}$ & $\begin{array}{l}\text { Low density turbidity } \\
\text { currents (Tabcde) }\end{array}$ & $\mathrm{B}$ and $\mathrm{C}$ \\
\hline
\end{tabular}


fans, because a great portion of the platform may be exposed, thus tapering the sediments through canyons and fans towards the slope. In high sea level stand periods, on the other hand, sediments tend to concentrate in lagoons and estuaries, or in environments near the coast, not reaching the platform and the feeding canyons (Stow, Howell \& Nelson 1985).

According to the lithofacies that have been identified and the sedimentary processes interpreted for the Canabravinha Formation (Tab. 2), a model of deep marine environment for the deposition of its protholits may be proposed. The deep marine sedimentation involves mainly gravitational sedimentation processes on a continuum of high density flows (blocks fall, drags, slides, mud and debris flows) to low-density turbidity currents. These flows interact directly with processes of pelagic and hemipelagic sedimentation (Stow, Reading \& Collinson 1996, Stow \& Mayall 2000).

The lithofacies of Columns A and B were probably deposited by gravitational sedimentary flows in the proximal portion of a gravel-rich slope-apron system (Reading \& Richards 1994, Richards, Bowman \& Reading 1998, Stow \& Mayall 2000). The slope-aprons form when there is a multiple linear source feeding the basin through a non-canalized system, directly into the slope. The fans form inter-related turbidity systems, so sheet or apron geometry is formed, making individual fan morphology unrecognizable. This type of sedimentation is well developed in fault-bounded margins such as submarine rifts in tectonically active basins, where a considerable amount of sediments is thrown through a steep slope to the adjacent basin, which is rapidly subsident (Fig. 6) (Reading \& Richards 1994). The turbidities of Column C represent the dilution of gravitational flows in the distal portion of the basin (Fig. 6).

\section{TECTONIC CONTEXT OF THE RIO PRETO}

BASINThe deposition of the sediments that compose the Canabravinha Formation probably occurred in a rift basin (Rio Preto basin), where the movements in normal faults favored the episodic origin of mud/debris flows that evolved to turbidity currents (Fig. 6). The mudflows were responsible for the deposition of diamictites, while their dilution resulted in high and low-density turbidity currents that caused sand and pelite layers to be deposited in proximal to distal turbidity sequences, from south to north (Fig. 6).
The association of lithofacies of the Canabravinha Formation and the predominance of coarse and immature sediments to the south, and of finer-grained sediments to the north, indicate that the sedimentary supply was mostly from south to north, therefore the main source area was the São Francisco Craton. The lithic content found in quartzite and clasts of diamictites support this hypothesis. The abundant occurrence of carbonate and granite fragments exempts the Rio Preto belt of being one of the source areas, for none of these rocks is found in the fold belt. It is thus difficult to conciliate a model of provenience exclusively from north towards south by erosion of the mountain chains that formed in the region, either by gravitational processes or by mountain glaciation (i.e. Gonzaga \& Walde 2007). On the other hand, the São Francisco Craton is full of granite and carbonaceous proterozoic covers that may have served as a source for the Canabravinha Formation debris.

\section{STRUCTURAL GEOLOGY AND TECTONICS OF THE RIO PRETO BELT The Rio Preto belt} represents a quilometric asymmetric divergent fan structure (Figs. 2 and 7), with a well-developed south portion with clear vergence to the São Francisco Craton, and a shorter north portion showing vergence to the north, where the Formosa Formation thrusts the Cristalândia do Piauí gneisses in low angle (EgydioSilva 1987). This structure is the result of a complex evolution that took place during the Brasiliano Oregeny, which generated three different secondary foliations associated with folds and oblique to transcurrent shear zone systems.

Egydio-Silva (1987) recognized the Cariparé shear zone (Figs. 2 and 7) as the boundary between the craton and the fold belt in the northwest region of Bahia, almost $60 \mathrm{~km}$ to the south of the previously proposed limit (Almeida 1977). Despite that, images of the craton in the scientific literature often ignore such limit in its northwest portion, and this fact should be considered in further publications.

The Cariparé shear zone constitutes an inverse fault with SW-NE orientation, 330-350/45 attitude and frontal kinematics, where the rocks of the Canabravinha Formation, in the north-northwest, are pushed onto the rocks belonging to the Bambuí Group, in the south-southeast. The main $\mathrm{S}_{2}$ foliation, in the Canabravinha Formation, is parallel to the slate cleavage in the cratonic cover of the 
Bambuí Group, in the transitional craton - fold belt region. The K-Ar ages in between $547 \mathrm{Ma}$ and Ma 595 obtained by Egydio-Silva (1987) in muscovite of the Canabravinha and Formosa Formations reinforce the hypothesis of this deformation having been originated during the Brasiliano Orogeny.

Three different deformation phases, possibly progressive, may be distinguished in the structural and tectonic evolution of the Rio Preto belt (Egydio-Silva 1987, Caxito 2010):

The $D_{1}$ phase generated the $\mathrm{S}_{1}$ penetrating foliation, which is generally parallel to $\mathrm{S}_{0}$. Little can be stated about the structures and the tectonic meaning of such phase due to the lack of data and posterior generalized transposition.

The $D_{2}$ phase is responsible for the developing of the $\mathrm{S}_{2}$ penetrating foliation, besides the remarkable structure in form of a double-vergence fan in the Rio Preto belt (Figs. 2 and 7).
In this phase, folds were formed in a gradient of style that vary from smooth and concentric, in the cratonic Bambuí Group, becoming progressively tighter towards the craton/fold belt boundary, with tight to isoclinal similar folds in the core of the Rio Preto belt. This phase also generated the ductile-brittle structures in the region, such as the Cariparé and Malhadinha shear zones. This phase of deformation is the closest to the metamorphic peak of the Brasiliano Orogeny in the Rio Preto belt, with the main metamorphic minerals oriented according to $\mathrm{S}_{2}$.

The $D_{3}$ phase is characterized by the $\mathrm{S}_{3}$ spaced crenulation cleavage or fracture cleavage (modal maximum: 187/32, n: 184), axial plan of smooth folds in $\mathrm{S}_{2}$, and possibly represents a final compressive phase comprising structures verging to the northwest, from the craton to the fold belt. Thrust faults sub-parallels to $\mathrm{S}_{3}$ may be found on BR-135

\begin{tabular}{|c|c|}
\hline São Francisco Craton & Rio Preto Fold Belt \\
\hline Bambuí Group & Canabravinha Fm. \\
\hline
\end{tabular}

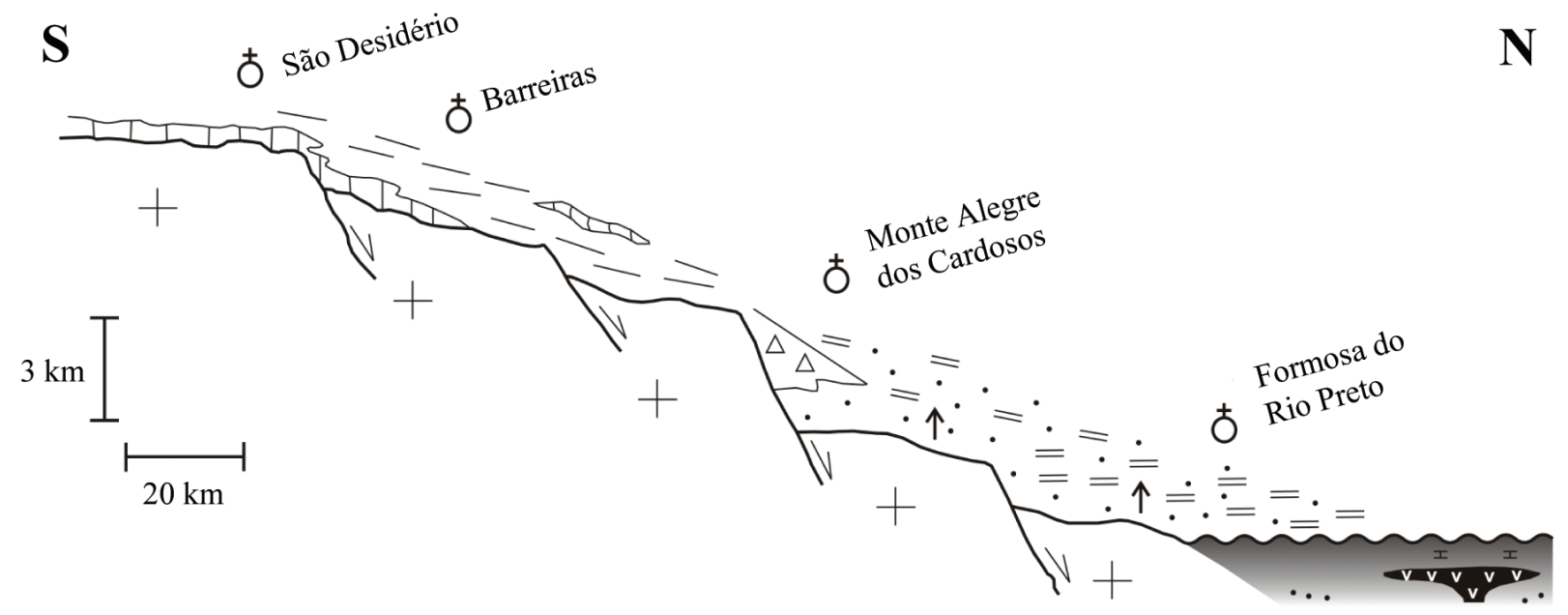

São Desidério Fm. Serra da Mamona Fm.

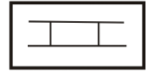

Limestone

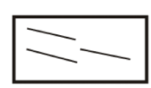

Pelite

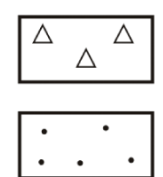

$\overline{=}=$ Pelite

Schematic position of cities

1 Graded bedding
Diamictite

Sandstone

Graywacke

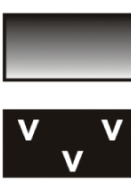

Formosa Fm. $(\sim 1.9 \mathrm{Ga})$

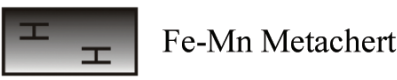

$\smile \begin{aligned} & \text { Erosive } \\ & \text { Unconformity }\end{aligned}$

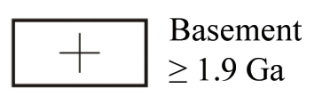

Figure 6 - Stratigraphic relations accross the São Francisco paleocontinent and neoproterozoic Rio Preto rift in a schematic $S-N$ section. 
road between Formosa and Malhadinha, with associated sigmoidal structures indicating frontal movement with top-to-northwest kinematics.

Fig. 7 shows $S_{2}$ and $L_{2}$ stereograms for the south, central and north portions of the Rio Preto belt (Caxito 2010, Caxito et al. 2010). From Cariparé to Malhadinha, $\mathrm{S}_{2}$ dips northwest (modal maximum: 334/29) (Fig. 7A), inclining progressively towards north until it reaches high angle to sub-vertical values in the region of Malhadinha (170/72) (Fig. 7B) and, from Formosa towards north, its inclination inverts to the southeast (139/15) (Fig. 7C).

The field study shows that the region of Malhadinha corresponds to a shear zone some kilometers thick by $80 \mathrm{~km}$ in outcropping extension, named Malhadinha-Rio Preto shear zone (Figs. 2 and 7) (Gonçalves Dias \& Mendes 2008, Caxito 2010, Caxito et al. 2010). This zone is composed of quartzite mylonites with subvertical $\mathrm{S}_{2}$ foliation and oblique-directional $\mathrm{L}_{2}$ lineation. The direction of reverse oblique dextral shear is indicated by a rounded geometry with S-deflection patterns, by structures in the field, and by microstructures in thin section such as S-C pairs, mica-fish and mantled porphyroclasts, and also by quartz crystalline structure orientation (Caxito 2010, Caxito et al. 2010).
A model of geotectonic evolution proposed for the Rio Preto belt involves crustal stretching during the Neoproterozoic Era $(\sim 850-600 \mathrm{Ma})$, with deposition of the Canabravinha Formation in a hemi-graben basin located within the Archean/ Paleoproterozoic basement of the region, that is, the Cristalândia do Piauí Complex and the Formosa Formation (Egydio-Silva 1987, Caxito 2010). Posteriorly, this basin was inverted during the Brasiliano Orogeny $(\sim 600-540 \mathrm{Ma})$, with the development of three phases of progressive deformation. The main phase, $\mathrm{D}_{2}$, generated a structure in the form of a quite peculiar asymmetric fan, whose possible causes are discussed by Egydio-Silva, Karmann \& Trompette (1990), Caxito (2010) and Caxito et al. (2010).

FINAL CONSIDERATIONS The Rio Preto belt has developed onto an Archean/Paleoproterozoic substrate $(\sim 2.8-2.0 \mathrm{Ga})$ of the Cristalândia do Piauí Complex. During the Orosirian period $(\sim 1.9 \mathrm{Ga})$, the deposition of the protholites of the Formosa Formation took place, with predominantly pelitic sedimentation and local chemical precipitation (iron-manganese metachert) possibly associated with basic magmatic activity (greenschist and ortho-amphibolite). The Formosa Formation was probably formed on a
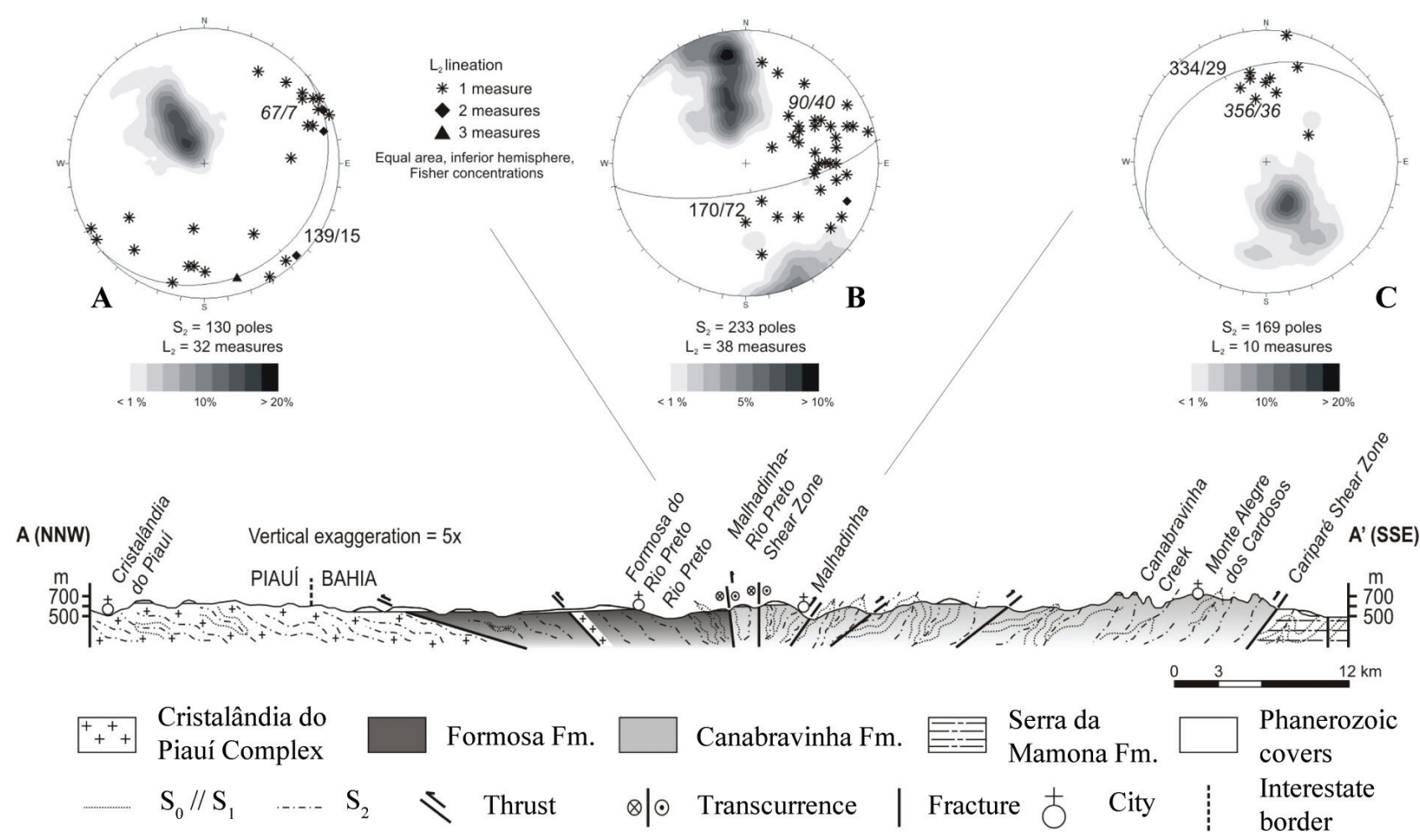

Figure 7 - Geological section and stereograms for $S_{2}$ and $L_{2}$ in the Rio Preto Belt. For section localization, see Fig. 2. 
basin related to a magmatic arc. The crustal block represented by the Formosa Formation and by the Cristalândia do Piauí Complex may have been through deformation and metamorphism of a paleoproterozoic orogenic cycle, as indicated by $\mathrm{Rb}$-Sr ages of the Cristalândia do Piauí Complex (Egydio-Silva 1987); this issue requires further detailed studies. A depositional hiatus marked by a unconformity of over one billion years separates the Formosa and Canabravinha Formations, the latter being formed during the Cryogenian to Ediacaran periods $(\sim 850-600 \mathrm{Ma})$.

The deposition of the Canabravinha Formation was caused by the opening of a rift with hemi-graben geometry, with a fault-bounded margin to the south and a possible flexural margin to the north. In the faulted margin, gravitational flows predominated in an submarine slope-apron, where mud flows graded to turbidity currents progressively more diluted to the north. There is no direct evidence for glacial sedimentation processes at the Rio Preto belt; however the possibility of reworking of glacial deposits by gravitational flows should not be excluded. During the Brasiliano Orogeny, in the Ediacaran Period $(\sim 600-540 \mathrm{Ma})$, the Rio Preto rift and its substrate went through structural inversion and metamorphism in the greenschist facies.

The ductile-brittle doubly-vergent asymmetric fan structure, with oblique to directional movement in the central portion of the fold belt, suggests destructive interaction in clockwise direction between the Cristalândia do Piauí block, to the north, and the São Francisco Craton, to the south. The total absence of orogenic magmatic rocks and oceanic reminiscences of Neoproterozoic age suggest evolution of the outcrop portion of the Rio Preto belt in an ensialic context, as a typical example of an intracontinental orogenic belt (Egydio-Silva 1987, Caxito 2010).

ACKNOWLEDGMENTS Conselho Nacional de Desenvolvimento Cientifico e Tecnológico (CNPq) (Process n ${ }^{\circ}$ 475510/2008-9) and Fundação de Amparo à Pesquisa do Estado de Minas Gerais (FAPEMIG) (CRA 505-06) for the financial support, the latter for providing scholarship for the first author Master's, and the geologist Felipe Rodrigues Martins for his assistance in field. The manuscript was improved after comments and suggestions by Dr. Fernando Vesely. We thank the staff of Revista Brasileira de Geociências for the editorial handling and English translation.

\section{References}

Alkmim F.F. 2004. O que faz de um cráton um cráton? O Cráton do São Francisco e as revelações almeidianas ao delimita-lo. In: Mantesso-Neto V., Bartorelli A., Carneiro C.D.R., Brito-Neves B.B. (ed.) Geologia do Continente Sul-Americano: evolução da obra de Fernando Flávio Marques de Almeida. Beca, São Paulo, p. 17-35.

Almeida F.F.M. 1967. Origem e evolução da plataforma brasileira. Boletim DNPM/DGM, 241, 36 p.

Almeida F.F.M. 1977. O Cráton do São Francisco. Revista Brasileira de Geociências, 7:349-364.

Andrade Filho E.L., Neves J.P., Guimarães J.T. (ed.) 1994. Programa levantamentos geológicos básicos do Brasil. Folhas Santa Rita de Cássia (SC.23-Z-C) e Formosa do Rio Preto (SC.23-Y-D), escala 1:250.000. SME/CPRM, Brasília: 68 p.

Arcanjo J.B.A. \& Braz Filho P.A. 1994. O mapeamento geológico das folhas Curimatá/Corrente - uma abordagem sobre os principais aspectos estruturais, estratigráficos e geomorfológicos. In: SBG, Congresso Brasileiro de Geologia, 38, Balneário Camboriú, Boletim de Resumos Expandidos, 2:106-107.

Arcanjo J.B.A. \& Braz Filho P.A. (ed.) 1999. Programa levantamentos geológicos básicos do Brasil. Folhas
Curimatá (SC.23-Z-A), Corrente (SC.23-Y-B-Parcial) e Xique-Xique (SC.23-Z-B-Parcial), escala 1:250.000. CPRM, Brasília: 84 p.

Barbosa J.S.F. 1982. O manganês do oeste da Bahia. Dissertação de mestrado, Universidade Federal da Bahia, Salvador, 129 p.

Boulton G.S. \& Deynoux M. 1981. Sedimentation in glacial environments and the identification of tills and tillites in ancient sedimentary sequences. Precambrian Research, 11:397-422.

Bouma A.H. 1962. Sedimentology of some Flysch Deposits: a graphic approach to facies interpretation. Amsterdam, Elsevier, 168 p.

Caxito F.A. 2010. Evolução tectônica da Faixa Rio Preto, Noroeste da Bahia/Sul do Piauí. Dissertação de Mestrado, Universidade Federal de Minas Gerais, Belo Horizonte, $151 \mathrm{p}$.

Caxito F.A., Uhlein A.; Morales L.F.G. 2010. Compartimentação estrutural da Faixa Rio Preto (NW da Bahia), um leque assimétrico de dupla vergência desenvolvido durante a Orogênese Brasiliana. In: SBG, Congresso Brasileiro de Geologia, 45, Belém, Anais.

Caxito F.A., Dantas E.L., Stevenson R., Uhlein A. 2011a. Geochemical, detrital zircon (U-Pb) and Sm-Nd 
isotopic insights into the sedimentary provenance of the Rio Preto Fold Belt, Northeastern Brazil. In: Schmitt R.S., Trouw R., Carvalho I.S., Collins A. (eds). Gondwana 14, Abstracts, Universidade Federal do Rio de Janeiro, Rio de Janeiro, p. 31.

Caxito F.A., Uhlein A., Dantas E.L., Stevenson R., PedrosaSoares A.C. 2011b. Petrography, geochemistry and geochronology ( $\mathrm{U}-\mathrm{Pb}$ and $\mathrm{Sm}-\mathrm{Nd}$ ) of amphibolites from the Rio Preto Fold Belt, Northeastern Brazil: Possible remnants of a Paleoproterozoic (1.96 Ga) subduction-related oceanic crust? In: Schmitt R.S., Trouw R., Carvalho I.S., Collins A. (eds). Gondwana 14, Abstracts, Universidade Federal do Rio de Janeiro, Rio de Janeiro, p. 32.

Dreimanis A. \& Schucluter C. 1985. Field criteria for the recognition of till or tillite. Palaeogeography, Palaeoclimatology, Palaeoecology 51:7-10.

Egydio-Silva M. 1987. O sistema de dobramentos Rio Preto e suas relações com o Cráton São Francisco. Tese de Doutorado, Universidade de São Paulo, São Paulo, 95 p.

Egydio-Silva M., Karmann I., Trompette R.R. 1989. Litoestratigrafia do Supergrupo Espinhaço e Grupo Bambuí no noroeste do estado da Bahia. Revista Brasileira de Geociências, 19(2):101-112.

Egydio-Silva M., Karmanm I., Trompette R.R. 1990. O sistema de dobramentos Rio Preto-borda NW do cráton do São Francisco. In: SBG, Congresso Brasileiro de Geologia, 36, Natal, Anais: 6:2658-2671.

Eyles N. 1993. Earth's glacial record and its tectonis setting. Earth-Science Reviews, 34:1-248.

Fuck R.A., Jardim de Sá E.F., Pimentel M.M., Dardenne M.A., Pedrosa-Soares A.C. 1993. As faixas de dobramentos marginais do Cráton do São Francisco: síntese do conhecimento. In: Dominguez J.M.L. \& Misi A. (ed.). O Cráton do São Francisco. SBG/SGM/ CNPq, Salvador, 121-146.

Gonçalves Dias T. \& Mendes M.C.O. 2008. Geologia da Faixa Rio Preto entre Formosa do Rio Preto e Malhadinha, Bahia. Trabalho de Graduação, Universidade Federal de Minas Gerais, Belo Horizonte, $62 \mathrm{p}$.

Gonzaga G.M. \& Walde D.H.G. 2007. Glaciação de montanha em faixas orogenéticas Brasilianas no Cráton do São Francisco? Uma revisão e uma proposta. Revista Brasileira de Geociências, 37(4 - suplemento): 234-243.

Inda H.A.V. \& Barbosa J.F. 1978. Texto explicativo para o mapa geológico do Estado da Bahia. SME/CPRM, Salvador, $97 \mathrm{p}$.

Jardim de Sá E.F. \& Hackspacher P.C. 1980. Reconhecimento estrutural na borda noroeste do Cráton São Francisco. In: SBG, Congresso Brasileiro de Geologia, 31, Balneário Camboriú, Anais, 5:2719-2731.

Johansson M. \& Stow D.A.V. 1995. A classification scheme for shale clasts in deep water sandstones. In:
Hartley A.J. \& Prosser D.J. (ed.). Characterization of Deep Marine Clastic Systems. Geological Society Special Publication n. 94, p. 221-241.

Lowe D.R. 1982. Suspended-load fallout rate as an independent variable in the analysis of current structures. Sedimentology, 35(5):765-776.

Mendes M.C.O., Gonçalves Dias T., Caxito F. A., Uhlein A., Sanglard J.C.D., Fujikawa L.H. 2010. Estudo das ocorrências de manganês e ferro da Faixa Rio Preto por microscopia eletrônica de varredura aliada a análises litoquímicas. In: SBG, 45 Congresso Brasileiro de Geologia, Belém, Anais, CD-ROM.

Miller J.M.G. 1996. Glacial sediments. In: Reading H.G. (ed.). Sedimentary environments: processes, facies and stratigraphy, 3rd ed., New York, Blackwell Scientific Publications, p. 454-484.

Moncrieff A.M.C. 1989. Classification of poorly-sorted sedimentary rock. Sedimentary Geology, 65:191-194.

Montes M.L., Monteiro N., Silva L.L. 1986. Geologia. In: PROJETO RADAMBRASIL, Folha SC-23, Rio São Francisco.

Moutinho da Costa L.A., Portela A.C.P., Marchetto C.M.L., Santos E.L., Meneguesso G. \& Stein J.H. 1971. Projeto Leste do Tocantins/Oeste do Rio São Francisco - LETOS. DNPM/CPRM/PROSPEC, Relatório Final Integrado, Petrópolis, Rio de Janeiro, 300 p.

Petri S., Coimbra A.M., Amaral G., Ponçano W.L. 1986. Guia de nomenclatura estratigráfica. Revista Brasileira de Geociências, 16(4):376-415.

Reading H. \& Richards M. 1994. The classication of deep water siliciclastic depositional systems by grain size and feeder systems. AAPG Bulletin, 78:792-822.

Richards M., Bowman M., Reading H. 1998. Submarine-fan systems I: characterization and stratigraphic prediction. Marine and Petroleum Geology, 15:689-717.

Sanglard J.C.D., Uhlein A., Caxito F.A., Suckau G.L. 2008. Estratigrafia e sistemas deposicionais da Faixa Rio Preto. In: SBG, Congresso Brasileiro de Geologia, 44, Curitiba, Anais, p. 14.

SantosA.R.; Meneses P.R., Santos U.P. 1977. Sensoriamento remoto aplicado ao mapeamento geológico regional Folha Rio São Francisco. Dissertação de Mestrado, INPE, São José dos Campos, 168 p.

Schermerhorn L.J.G. 1974. Late Precambrian mixtites: glacial and/or non glacial? American Journal of Science, 274:673-824.

Stow D.A.V., Howell D.V., Nelson C.H. 1985. Sedimentary, Tectonic and Sea-Level Controls. In: Bouma A.H., Normark W.R. \& Barnes N.E. (ed.), Submarine Fans and Turbidite Systems, Frontiers in Sedimentary Geology, Springer-Verlag, $351 \mathrm{p}$.

Stow D.A.V., Reading H.G., Collinson J.D. 1996. Deep Seas. In: Reading H.G. (ed.), Sedimentary environments: processes, facies and stratigraphy, 3rd ed., New York, Blackwell Scientific Publications, p. 395-453. 
Stow D.A.V. \& Mayall M. 2000. Deep-water sedimentary systems: New models for the $21^{\text {st }}$ century. Marine and Petroleum Geology, 17:125-135.

Trompette R.R. 1994. Geology of Western Gondwana (2000-500 Ma). Pan-African-Brasiliano aggregation of South America and Africa. Balkema, Rotterdam, $350 \mathrm{p}$.

Uhlein A., Alvarenga C.J.S., Trompette R.R., Dupont H.S.J.B., Egydio-Silva M., Cukrov N., Lima O.N.B. 2004. Glaciação neoproterozóica sobre o cráton do São Francisco e faixas dobradas adjacentes. In: MantessoNeto V., Bartorelli A., Carneiro C.D.R., Brito-Neves B.B. (ed.) Geologia do Continente Sul-Americano: evolução da obra de Fernando Flávio Marques de Almeida, Beca, São Paulo, p. 539-553.

Uhlein A., Egydio-Silva M., Caxito F.A., Sanglard J.C.D., Suckau G.L., Mendes M.C.O., Gonçalves Dias T., Uhlein G.J. 2008. As faixas dobradas da margem norte do Cráton do São Francisco: estratigrafia e tectônica. In: SBG, Congresso Brasileiro de Geologia, 44, Curitiba, Anais, p. 6.

Manuscrito ID 24625

Recebido em: 10/10/2011

Aprovado em: 23/04/2012 